\title{
Islam and Public Services: Evaluation of Local Regulations Concerning Living Values Religious Community In Tasikmalaya City
}

\author{
Fikri Zulfikar ${ }^{1}$, Suswanta $^{2}$, Misran $^{3}$, Dyah Mutiarin $^{4}$, Achmad Nurmandi $^{5}$, Arissy Jorgi Sutan ${ }^{6}$ \\ \{misranalfarabi@gmail.com ${ }^{3}$ \} \\ Department Government Affairs Administration, Jusuf Kalla School of Government, \\ Universitas Muhammadiyah Yogyakarta ${ }^{1,2,3,4,5,6}$
}

\begin{abstract}
This study aims to explain the evaluation of Regional Regulation Number 7 of 2014 concerning the Value of Religious People in the City of Tasikmalaya. In addition, the purpose of this study is to find out the legal truth for the community. This research uses a qualitative approach with a case study method. Primary Data and Secondary Data Types of data: Primary data from this study include interviews with the local government of Tasikmalaya City and the community, especially the leaders of mass organizations who directly experience the local regulations and other figures involved. Secondary data is supporting data sourced from literature and documents related to the object/location of research. The finding of this research is that this regional regulation has not been implemented properly because its implementation only applies to Muslims. Whereas initially there was another goal: mutual respect and respect for other religions. From the results of evaluation and observation, the existence of a regional regulation will have the same impact because this regional regulation does not protect the wishes of the entire community. However, as an icon of the City of Tasikmalaya with local regulations that protect the majority of Muslims, this is a real success. This regional regulation can be used as a reference to maintain the norms and values of Tasikmalaya residents, so that cultural values as a Muslim student city in Tasikmalaya City are maintained.
\end{abstract}

Keywords: Local regulation; Public policy; Evaluation

\section{Introduction}

In the current era, with discussions about innovation and Islamic nationalism, the discourse on the implementation of Sharia Regional Regulations also continues to run with the emergence of various kinds of issues and problems that change the mindset of local officials to continue discussing them (Mahendra 2007). The assumption of Islamic values that make Regional Regulations known as regional policies lies mainly in Islamic values. Many people accept that implementing this Islamic Shari'a Regional Regulation policy is considered a very 
noble goal. However, on the other hand, some people disagree with the policies that have been implemented in some of these areas.

For a group of people, the implementation of this Regional Regulation is considered capable of restoring the moral welfare of the community in their environment. Shari'a Regional Regulations appear to intend to create order and peace in people's lives. The enactment of regional autonomy is a great opportunity for regions with a large Islamic mass base. These regions have solid Islamic traditions to make regional regulations with Islamic nuances because many parties consider this Shari'a Regional Regulation a good solution considering the many problems that often occur regarding morals and welfare in society which have begun to decline. Regional autonomy is an opportunity for the community to actualize Shari'a Regional Regulations, which were previously prevented by regional officials or state regulations. At this time, various regions implement policies with the nuances of Islamic law, from 512 districts/cities in Indonesia, approximately 64 districts and cities in 15 provinces in Indonesia have issued and implemented regulations with the nuances of Sharia in each of them (Arfiansyah 2015)

Tasikmalaya is known as one of the cities that has stipulated several Sharia Regional Regulations. This is due to the prior support from various political parties and Islamic organizations given to the City and Regency of Tasikmalaya politically and culturally to residents (Al-Barbasy 2016). The city and district of Tasikmalaya have become one of the areas that have been widely discussed because they have succeeded in fighting for and enacting several Shari'a regulations.

This study examines the Shari'a regional regulations in the City of Tasikmalaya, especially regarding Regional Regulation Number 7 of 2014 concerning the Values of Religious Community Life. Before the enactment of the regional regulation, the Tasikmalaya City Government had a similar regulation, namely Regional Regulation Number 12 of 2009 concerning the Development of Values for Community Life Based on Islamic Teachings and Social Norms of the Tasikmalaya City Community, which the Tasikmalaya City Government stipulated on August 31, 2009, However, many things have become polemic and controversial from the presence of this Perda, both in local and national contexts. So that in 2014 this Regional Regulation was revoked and declared invalid, which was later updated to become Regional Regulation Number 7 of 2014 concerning Values of Religious Community Life in the City of Tasikmalaya.

The Regional Regulation is an initiative of kyai from various types of Islamic boarding schools and non-mainstream Islamic community organizations such as HTI, FPI, Laskar Taliban, and PKPPSI in Tasikmalaya City (AL-BARBASY 2016). Although, in the end, all Islamic organizations in the City of Tasikmalaya agreed with the regulation, the forms of support for the regional regulation turned out to be varied, as shown in the table below.

Table 1. Forms of support for Islamic organizations on the Shari'a Regional Regulation

\begin{tabular}{ccccc}
\hline No. & & \multicolumn{3}{c}{ Forms of Support for Islamic Organizations } \\
\hline & Refuse & \multicolumn{2}{c}{ Critical Support Support With Change } & Support Aceh Version \\
\hline 1 & PMII & Nahdatul Ulama & FUI & FPI \\
2 & GP. Ansor & Muhammadiyah & Al-Washliyah & Taliban Warriors \\
3 & LKAHM & Mathlaul Anwar & Persis & FPI \\
4 & - & - & - & PKPPSI \\
\hline \multicolumn{4}{c}{ Sumber: (Al-Barbasy 2016) }
\end{tabular}

The regulation initially took the form of the Qanun in Aceh. However, after referring to higher regulations, according to Law Number 32 of 2004 concerning regional government, the 
City of Tasikmalaya is an autonomous region with exceptional autonomy, so it must be adjusted to the corridor of the higher regulation.

There are several reasons why this research was conducted in Tasikmalaya City. First, the City of Tasikmalaya is an area that can stipulate various kinds of regional regulations with an Islamic Shari'a nuance such as the Regional Regulation of the City of Tasikmalaya Number 7 of 2015 concerning Control and Supervision of Alcoholic Beverages in the City of Tasikmalaya, Regional Regulation of the City of Tasikmalaya Number 7 of 2014 concerning the Values of Community Life Religion in Tasikmalaya City, Tasikmalaya City Regional Regulation Number 2 of 2011 concerning Early Education in Tasikmalaya City and Regulations

Tasikmalaya City Region Number 12 of 2009 concerning the Values of Community Life. Second, Tasikmalaya City is an area that has a solid Islamic political, historical value. Historically, Tasikmalaya has been known as a reasonably large DI/TII and Masyumi base. In the 1955 elections, Masyumi was the winner of Tasikmalaya and West Java (AL-BARBASY 2016). DI/TII and Masyumi are considered the roots of the rise of Islamic law in Indonesia. Third, the City of Tasikmalaya is an area that genuinely responds to demands from various groups to determine the later implementation of regional regulations that refer to sharia. Fourth, the City of Tasikmalaya area is an administrative area where Islamic mass-based parties dominate. The election results also show that in the 2009 election, political victories were dominated by parties with an Islamic mass base, with 27 seats or around $60 \%$, while the nationalist parties obtained fewer seats, namely 18 seats or around $40 \%$.

Following the next election in 2014, Islamic parties still showed their existence even though it decreased compared to the previous election by getting 24 seats or around $53.3 \%$. On the other hand, nationalist-based parties get 21 seats or around $46.7 \%$. The fifth is the distribution of the population based on religion in the City of Tasikmalaya. Although Tasikmalaya City is predominantly Muslim, there are still many people in Tasikmalaya City who have other religions. Based on some of the presentations that have been described above, there are many things behind the author to identify and explain the evaluation of the phenomenon of the Shari'a Regulation regarding the values of religious community life in the City of Tasikmalaya.

\subsection{Policy Evaluation}

The implementation of a policy will undoubtedly determine an outcome that is desired following the reasons for the policy. Therefore, public policy must have supervision and, of course, an evaluation to find out whether the impact implemented or implemented from the policy has an appropriate impact or not. Stewart and Lester state that the evaluation is also intended as an illustration in seeing some of the failures of a policy and to find out whether the policies that have been formulated and implemented can produce the desired impact. Meanwhile, assessing policy outcomes is very important. Jones states that public policy evaluation is an activity designed to assess policy outcomes that are very important in the specification of their objects, measurement techniques, and analysis methods. The evaluation aims to find deficiencies and cover deficiencies, is (Nugroho 2008) stated by which states that the characteristics of policy evaluation are:

1. The goal is to find strategic things to improve policy performance.

2. Evaluators can distance themselves from policymakers, policy implementers, and policy targets. 
3. Methodologically accountable procedures are carried out not in an atmosphere of hostility or hatred.

4. It is not carried out in enmity or hatred.

5. Includes policy formulation, implementation, environment, and performance.

There are at least 3 (three) policy evaluations aimed at measuring the impact for the entire community and the extent to which the stated objectives have been achieved, according to James in (Nugroho 2008) stating that dividing the evaluation (implementation) of public policies into three. The first type, the evaluation of public policy, is understood as a functional activity; the second evaluation focuses on the workings of the policy. Third, a systematic policy evaluation looks at policy programs objectively to measure their impact on society and the extent to which the stated objectives have been achieved.

To assess policies that include substance, Anderson's opinion (Winarno 2013) (in Winarno, 2008: 226) states that general policy evaluation can be an activity that involves the estimation or assessment of policies that include substance, implementation, and impact. Furthermore, to know the evaluation of policies in terms of the objectives to be achieved, according to Thomas Dye (Winarno 2008) 1 stated that policy evaluation is an objective, systematic, and empirical examination of the effects of public policies and programs on their targets in terms of the goals they want to achieve. Achieved.

Furthermore, to measure the policy objectives that have been set according to Weiss (in Widodo, 2006: 114) states that evaluation research aims to measure the impact of a program that leads to the achievement of a set of goals that have been set and as a means to contribute (recommendations) in making future program decisions and improvements.

\subsection{Policy Evaluation Indicators}

There are quite a several indicators regarding policy evaluation that experts have put forward. As according to Finster Busch and Motz, (1980) in Bingham and Felbinger, Howlet and Ramesh (1995) in (Nugroho 2008), James Anderson in (Winarno 2008), and (William N. Dunn 2003a). Dunn and other authors provide an overview of indicators to measure the evaluation of existing policies. In this study, the authors use the policy evaluation indicators that Dunn has proposed. The author considers that this indicator is the most appropriate for knowing or assessing the effectiveness of the public policy for the community. Dunn provides a fairly complete evaluation compared to the others so that it will make the evaluation of this policy more complete for researchers.

In the implementation of policy evaluation, general criteria are used, which are intended to provide direction for evaluators. The criteria formulated will be used as a benchmark in determining whether a policy is successful or unsuccessful. Dunn describes policy evaluation criteria which include 6 (six) types as follows (William N. Dunn 2003b)

\section{a) Effectiveness (Effectiveness)}

About whether an alternative achieves the expected result (effect) or achieves the purpose of the action. Effectiveness, closely related to technical rationality, is always measured by the unit of product or service or its monetary value.

\section{b) Efficiency}


Concerning the amount of effort required to increase a certain level of effectiveness. Efficiency, synonymous with economic rationality, is the relationship between effectiveness and effort, the latter generally being measured by monetary costs. Concerned with how far a level of effectiveness satisfies the need, value, or opportunity that gives rise to the problem.

\section{c) Equity}

This indicator is closely related to legal and social rationality and refers to the distribution of outcomes and efforts between different groups in society. Smoothing-oriented policies are policies in which the consequences (e.g., units of service or monetary benefits) or effort (e.g., monetary costs) are equitably distributed. Based on equality criteria, policies designed to distribute income, educational opportunities, or public services are sometimes recommended. The criterion of equality is closely related to competing conceptions of justice or fairness and to ethical conflicts around an adequate basis for distributing risorsis in society.

\section{d) Responsiveness (Responsiveness)}

Concerning the extent to which a policy can satisfy specific community groups' needs, preferences, or values. The responsiveness criterion is essential because an analysis that can satisfy all other criteria such as effectiveness, efficiency, adequacy, and equality will still fail if it has not responded to the actual needs of the groups that should benefit from the existence of a policy.

\section{e) Accuracy (Appropriateness)}

The criterion of appropriateness is closely related to substantive rationality because the question of policy appropriateness is not concerned with an individual set of criteria but two or more criteria together. Accuracy refers to the value or value of program objectives and the strength of the assumptions underlying these goals. Public service.

Currently, public services and policies have a very close relationship in their implementation. The public policy itself is a decision binding on the people at a strategic or outline level made by the holder of a public authority. As a binding decision on the public, public policy must be made by political authorities, namely, those who receive a mandate from the public or the people, generally through an electoral process to act on behalf of the people.

Furthermore, public policies will be implemented by the state administration, which is run by the government bureaucracy. The main focus of public policy in a modern state is public services, which are all forms of services, both in the form of public goods and services, which in principle are the responsibility and are carried out by the state to maintain or improve the quality of life of the people.

In its implementation, this public policy must be revealed in a series of implementation instructions and technical instructions that apply internally to the bureaucracy. Meanwhile, from the community side, what is important is the existence of a public service standard, which describes to the community what services they are entitled to, who can get them, what requirements, and what form of service it is. To realize this desire and make the policy effective, at least three things are needed (Dachi 2017) 
1. The existence of legal instruments in the form of statutory regulations so that the public can know what has been decided.

2. This policy must have a straightforward implementation and financing structure.

3. The existence of public control, namely a mechanism that allows the public to know whether this policy in its implementation is experiencing deviations or not.

\subsection{Islamic Shari'a and its Relationship with the State}

The issue between Islam and the state in modern times is one of the essential subjects. Although Islamic thinkers have debated it since almost a century ago until today, it has not been entirely resolved. Long debates often occur to answer the question: which country can be called a country that is a prototype (archetype) of an Islamic state, whether Saudi Arabia or Iran and even Pakistan can be called an authentic Islamic state representation or not at all (Azra 2016).

In-depth, in Islamic literature, there are two debates regarding the state itself, namely the secular state and the Islamic State, better known as the caliphate. In the Sunni tradition, the concept of an Islamic state is not an option for a state. The concept of a separate state is better known as more easily interpreted as a government made by the people, for the people, and from the people. A government is not born from God, who was sent down specifically for humans. Therefore, the tendency is a secular state. While different views exist in the Shia tradition, the concept of an Islamic state or caliphate is more appropriate to be applied and becomes their main thought (Al-Hamdi 2013).

Several Muslim scholars in such situations have launched creative and critical thoughts around the relationship between Islam and the state. According to Nurcholis, the value of the state and government in Islam is instrumental. The point of all the desired points in Islam is piety to God. So the government or the state is realized to create space and time as a place for every human being to develop his piety to God. Nurcholis added that Muslims do not need to demand this state or government become an Islamic state or government. For him, what is important is the content or substance, not the standard form. The standard form is useless if the content does not change. So this country may be whatever its form, claim, or recognition. But the values or values that are carried out are the values desired by God, which are pleasing to God. A country like this can be grown through a cultural approach, a cultural approach in the broadest sense. This includes education, da'wah, art, and among the most important is Intellectual Islam essentially brings its teachings in various perspectives of human life, which are sourced from the Qur'an and Hadith. The validity of these two sources has been acknowledged and stated that it would not change according to changing times. However, what can change and will continue to evolve is the interpretation of Islam in specific contexts. Based on the definition put forward, it can be understood that the relationship between politics and the state cannot be separated. Regarding the state, it will not be separated from the political context, either as a system of government regulation or as an authority or power in a country.

To find out the relationship between Islam and the state stated in various classical Islamic literature, several formulations regarding the elements of the state were found. Among them, the formulation of Ibn Abi Rabi' quoted by Syaraf and Muhammad Abd al-Mu'thi mentions that at least five elements must be owned by the state, namely territory, population, government, justice, and state management. Meanwhile, Al-Mawardi also wrote five main elements: religion as the foundation of the state and the unity of the people, territory, population, authoritarian government, and justice or security. In principle, the definitions that 
have been put forward all agree on the prerequisites for a country to have at least the following: a sovereign territory, a system of government, and the people. However, at the application level in adopting the government system, there are differences. Some are inspired by religious values formally, others are based on the substantialism of religious values, and the government system is adapted to the socio-community conditions and groups that take embarkation between religions. And each country stands alone, and this group is included in the flow of secularism.

In Indonesia, although the prevailing laws and regulations are based on Pancasila and the 1945 Constitution, it does not rule out the possibility of a positive correlation with Islamic sharia values. The stipulation of several Islamic laws proves this as national law, such as national law, such as family law which includes the law of marriage, inheritance, grants, endowments, and so on. Thus, Pancasila, which is the source of all relevant legal sources in Indonesia, still opens up opportunities for religious law principles, such as Islamic law, to be applied and at the same time enrich the treasures of the national legal system.

\section{Methods}

In this study, researchers used a qualitative approach with a case study method (case study).

\subsection{Primary Data}

Primary data is data obtained directly from observations and interviews by resource persons/informants at the object/location of research. Primary data from this study include interviews:

Table.2. Interviewed Informants

\begin{tabular}{ll}
\hline Tasikmalaya City Local Government & $\begin{array}{l}\text { Implementation of the Shari'a Regional Regulation } \\
\text { in the City of Tasikmalaya. } \\
\text { The party who bridges to make a local regulation in } \\
\text { the City of Tasikmalaya. }\end{array}$ \\
$\begin{array}{l}\text { Religious organizations and Islamic } \\
\text { political parties in Tasikmalaya City }\end{array}$ & $\begin{array}{l}\text { An essential reference as a party that provides } \\
\text { initial views before the implementation of the } \\
\text { regional regulation. }\end{array}$ \\
Tasikamalaya City Community, & $\begin{array}{l}\text { Elements that feel the direct impact of the } \\
\text { implementation of local regulations on religious, } \\
\text { social values. }\end{array}$ \\
\hline
\end{tabular}

\subsection{Secondary Data}

Secondary data is data obtained indirectly related to the object of research. Secondary data in the form of supporting data sourced from literature and documents related to the object/location of research. In this study, laws and regulations from the government and literature books become secondary sources by researchers.

\subsection{Data Collection Techniques and Data Analysis}

The process of collecting data by researchers is carried out through three stages including: 




\section{Result and Disscusion}

\subsection{Evaluation of the Shari'a Regional Regulation on the Values of Religious Community Life in the City of Tasikmalaya}

With the enactment of Regional Regulation Number 7 of 2014 concerning Values of Religious Community Life in the City of Tasikmalaya, the local government already has an apparent reference and legal basis for implementing the regulation to resolve the problems in the City of Tasikmalaya.

Stipulation and implementation of regional regulations with Islamic sharia nuances starting from Regional Regulation Number 12 of 2009 concerning Development of Community Values. Based on Islamic Teachings and Community Norms of Tasikmalaya City until later revised and improved by the Regional Government through the Tasikmalaya City DPRD so that it becomes a Regional Regulation Number 7 of 2014 concerning Values of Religious Community Life in the City of Tasikmalaya has its advantages and disadvantages, there are several things that according to the author must be considered in the application of this regional regulation as according to Dunn there are criteria that must exist in policy evaluation.

\subsection{Effectiveness}

The implementation of this regulation has programs that have been arranged in each part of the chart, but the implementation of the program has been. Implementing whether to achieve the expected results (results), of course, contains many opinions.

Based on the analysis results from the existing sources, it can be said that this Regional Regulation is still not following the expectations of the objectives and reasons for the formation of this regulation. There are still programs that are felt to be a habit that makes it seem as if there is, and in the absence of this regulation, the results will be the same. Of 
course, the following is an overview of the evaluation analysis based on the programs and activities carried out:

First, in maintaining religious beliefs, the program implemented by the Tasikmalaya City Government is very discriminatory and can be said to be exclusive to Islamic shari'ah activities. For example, the call for the construction of a prayer room/mosque in a private company (Mall/Hotel/Karaoke), the implementation of reading the Qur'an before work, stopping every work activity before the call to prayer, the Magrib recital movement, and so on.

Second, in moral development, the program implemented by the Tasikmalaya City Government has become a habit and culture of the people in Tasikmalaya City. This means that it is not a program that becomes a breakthrough and instead only continues through the claims made by the regulations - for example, implementing the commemoration of Islamic holidays (PHBI), the commemoration of other religious holidays, and others.

Third, in the development of education, it is still the same as before, apart from the program carried out exclusively by Islamic law and the program of activities before there was a Regional Regulation was even some schools had implemented it. For example, the implementation of the Ramadan Islamic boarding school, a flash boarding school during the holidays, the liaison of the Koran teacher, the implementation of the obligatory prayers in congregation and the Duha prayer, and so on.

Fourth, economic development still emphasizes activities that are Islamic in nature. For example, the implementation of the Tasikmalaya movement in charity, appeals for buying and selling following sharia, controlling halal food and drinks, distributing compensation in the month of Muharram, and others.

And fifth, in dress etiquette, the program implemented by the Tasikmalaya City Government is still the same apart from being shari'a. All elements of society have not thoroughly felt it. For example, the appeal for Muslim civil servants to wear the star's hijab, the arrangement of dress code in the company, an appeal to dress according to values in public places, and so on.

\subsection{Efficiency}

Efficiency is closely related to the amount of effort (cost) required to produce the desired level of effectiveness. In this case, there is no clarity on the details of the budget used for program implementation from the implementation of Regional Regulation Number 7. The budget is crucial for developing a program and implementing Regional Regulation Number 7 of 2014 in Tasikmalaya City.

Efficiency becomes a benchmark as the policy can target its goals and objectives. Taking into account efficiency, of course, it is also required to consider the budget allocated for a program. This is because the budget is crucial for developing a program, especially regarding implementing the Regional Regulation Number 7 of 2014 in the City of Tasikmalaya. In this case, the measure of whether the program can run sustainably is undoubtedly seen through the availability of the allocated budget.

The budget allocated for a legal product of the Regional Regulation on values compared to other Regional Regulations in the City of Tasikmalaya is often very small. The budget was reduced by Rp. 500,000,000, - and the City Government of Tasikmalaya issued a small budget for social purposes. On the other hand, the larger budget was emphasized for infrastructure development. 
The above is inversely proportional if you look at the Facilitation Program for the Implementation of Religious Activities as a whole, the budget allocation for the facilitation of religious activities based on the 2016 Government Agency Performance Report (LKIP) was Rp. $15,494,820,500.00$, and the realization was Rp. 14,675,901,724.00. or $94.71 \%$; This activity is carried out by the Regional Secretariat and throughout the district. From the known amount, it can be concluded that the budget amount can be measured on the priority scale of the program. Especially, in this case, programs related to religious activities are included in the priority programs of the City of Tasikmalaya government.

Then, at this point, of course, it will be concerned with how far a certain level of effectiveness satisfies the need, value, or opportunity that gives rise to the problem. As explained in Regional Regulation Number 7 of 2014, it refers more to the strengthening of appeals. However, it does not mean an appeal to rule out the application of administrative sanctions in this case. Administrative sanctions are applied and may include: 1) warning, 2) written warning, 3) activity termination and 4) license revocation. On the other hand, the phenomena that occur in the field and their correlation with the existence of Regional Regulations and the absence of Regional Regulations can still be the same because the existence of Regional Regulations does not have a real influence on values in society. This was due to 2 factors before the Regional Regulation was implemented; first, the level of violations is enormous, and second, social problems are getting higher and unresolved.

Administrative sanctions are one of the elements of Regional Regulations which are intended to provide awareness for violators. When administrative sanctions are weak, the probability of violation is higher or vice versa. Violations are seen very much but not revealed and not recorded. In this case, the use of administrative sanctions is to minimize the occurrence of violations.

\subsection{Alignment}

Then this point discusses related to the distribution of policy benefits. The implementation of the norms carried out by the Tasikmalaya City Government has only been running for a few elements such as government, offices, educational institutions, and private companies. In addition, the Tasikmalaya City Government's policy focuses more on religious adherents of Islam. It can be said that this has not been effective in building the overall value system of society. Because equity includes multi-dimensional aspects, especially in all elements of urban development

Furthermore, this then becomes the main focus of the Tasikmalaya City government. It prioritizes making comprehensive and equitable programs and further suppresses reducing social problems related to the development of community values in the City of Tasikmalaya.

\subsection{Responsiveness}

Talking about responsiveness certainly talks about how far a policy can satisfy the needs, preferences, or values of the community groups that are the target of the policy. In this case, the importance of community involvement in optimizing policy implementation is part of a measure of success that supports implementation to run correctly and correctly. The participation of the community who are members of the implementation of the Regional Regulation implementation, including:

1. There is a kyai/ajengan/ustad who initiates the formation of Regional Regulations up to the implementation stage 
2. The existence of Ormas/Youth Leaders/Community Leaders who participate in overseeing the implementation of the implementation in the field

3. Employees/employees/students/students as policy implementers, although in general the community still has not implemented it optimally

4. Cooperation between the local government and private companies

Since the enactment of Regional Regulation No. 7 of 2014, the City Government of Tasikmalaya, through Kesbangpol, has collaborated with private companies and related agencies, which have become responsible for making appeals in building community values. For example, the application of dress ethics at Bank Jabar, which initially did not wear a veil and now covers the genitals, is the same as in other companies. In addition, the necessity to build proper places of worship in every company, be it hotels or malls, is a form of community responsiveness. If some of the elements contained in the Regional Regulation are not fulfilled, the company's license will be revoked. This is solely to create and build the values of the people of Tasikmalaya City.

More detailed involvement is carried out through the composition of the Coordination Team for the Implementation of the Values of Religious Community Life in the City of Tasikmalaya, which attempts to reach all elements of society, from the government, local government, and community, to universities.

\subsection{Accuracy}

Concerning whether the policy is appropriate for a society, it turns out that in the implementation of Regional Regulation Number 7 of 2014 concerning the Values of Religious Community Life, which has been regulated in the Mayor's Regulation, there are still irregularities found in the field. This means that the program implemented is not felt by all elements of society. The program is very discriminatory, and the program offered is a habit or culture of the people of Tasikmalaya City. As a result, the implementation can not be said to be optimal. As explained below, among others;

It begins with a question regarding whether the policy is suitable for a society? In fact, in the implementation of Regional Regulation Number 7 Tahim 2014 concerning Values of Religious Community Life, it has been regulated in the Mayor's Regulation. There are still irregularities found in the field. The problem is that the programs implemented cannot be felt by all elements of society, in this case, the relation is more inclined to very discriminatory programs, and also the programs offered are habits or culture of the people of Tasikmalaya City that already existed first and were carried out as in general. As a result, in its implementation, it can be said that it cannot be maximized. As explained below, among others; First, in maintaining religious beliefs, the program implemented by the Tasikmalaya City Government is very discriminatory and can be said to be exclusive to Islamic shari'ah activities. For example, the call for the construction of a prayer room/mosque in a private company (Mall/Hotel/Karaoke), the implementation of reading the Qur'an before work, stopping every work activity before the call to prayer, the Magrib recital movement, and so on.

Second, in moral development, the program implemented by the Tasikmalaya City Government has become a habit and culture of the people in Tasikmalaya City. This means that it is not a program that becomes a breakthrough and instead only continues through the claims made by the regulations, for example, implementing the commemoration of Islamic holidays (PHBI), the commemoration of other religious holidays, and others. 
Third, in the development of education, it is still the same as before, apart from the program carried out exclusively by Islamic law and the program of activities before there was a Regional Regulation was even some schools had implemented it. For example, the implementation of the Ramadhan boarding school, the existence of a flash boarding school during the holidays, the liaison of the Koran teacher, the implementation of the obligatory prayers in congregation and the dhuha prayer, and so on. Fourth, economic development still emphasizes activities that are Islamic in nature. For example, the implementation of the Tasikmalaya movement in charity, appeals for buying and selling following sharia, controlling halal food and drinks, distributing compensation in the month of Muharram, and others. And fifth, in dress etiquette, the program implemented by the Tasikmalaya City Government is still the same apart from being shari'a. All elements of society have not thoroughly felt it. For example, the appeal for Muslim civil servants to wear the syar'i hijab, the arrangement of dress code in the company, an appeal to dress according to values in public places, etc.

Before establishing this Regional Regulation Number 7 of 2014, matters related to the development of values and norms in society have been implemented. Moreover, the programs built by the City Government of Tasikmalaya, for example, are related to the construction of a prayer room, the Maghrib Koran movement, the commemoration of Islamic holidays, dress etiquette, and others. When the Regional Regulation is presented to the santri and students, it looks like it will become a problem. This value system does not need to be regulated in the Regional Regulation because it has become a habit in schools and Islamic boarding schools. Understanding and practice of the value system have been structured to know something good and evil. This is where the existence and absence of Regional Regulations are the same unless they are implemented correctly and adequately and become a breakthrough for something new following the community's needs.

However, speaking of Regional Regulation Number 7 of 2014, it is seen as not a matter of right or not and not a matter of being effective or not; if the Regional Regulation is intended to strengthen values in society, of course, it becomes legitimate. Moreover, it can be used as a characteristic of an area, namely in the form of legality that regulates society's values in the City of Tasikmalaya. In the implementation of Regional Regulations, as described, the measure of success in implementation can be said to have not been maximized. The following is a summary that causes the implementation of Regional Regulation No. 7 of 2014 in the City of Tasikmalaya, including:

1. The program implemented by the Tasikmalaya City Government is not following the Tasikmalaya City Master plan

2. The community has not fully implemented it in general

3. This Regional Regulation Number 7 of 2014 is not needed in the community

4. Regional Regulation Number 7 of 2014 exclusively applies only to Muslims

On the other hand, problems related to the implementation of Regional Regulation Number 7 of 2014 are social problems that can affect people's behavior, with patterns and sub-cultures that develop in society. The tendency if there is no effort to build is not just an appeal. Naturally, the community's values will be aware of itself. Related to the above conditions, an approach model is needed to change the community's values by taking into account the factors that influence it. Social problems that have not been resolved so far in the City of Tasikmalaya. This fact shows that things have not been maximized, primarily in program making as previously explained, through Regional Regulation Number 7 of 2014 to minimize problems in the City of Tasikmalaya. 


\section{Conclusion}

Applying regional regulations based on Islamic law in the City of Tasikmalaya has a relatively long process. It is not easy starting from Regional Regulation Number 12 of 2009 concerning the Development of Values-Based on Islamic Teachings and Community Norms of Tasikmalaya City, which openly shows these rules. Strongly sided with the Islamic religion, which was later revised and refined by Regional Regulation Number 7 of 2014 concerning the Values of Religious Community Life in the City of Tasikmalaya.

The existence of this change is certainly not without reason. This is the result of an evaluation by the Central Government through the Ministry of Home Affairs, which states that Regional Regulation Number 12 of 2009 concerning Development of Values. The Islamic Teachings and Community Norms of the City of Tasikmalaya contradicts higher regulations, namely law No. In addition, it is feared that this regulation will cause conflict and discrimination against other groups.

Although in the end, the changes made by ratifying Regional Regulation Number 7 of 2014 concerning Values of Religious Community Life in the City of Tasikmalaya were only limited to editorial changes and did not change the content of the substance. As for why the Regional Regulation Number 7 of 2014 concerning Values of Religious Community Life in the City of Tasikmalaya was formed first, this regional regulation is a cultural strengthening of the City of Tasikmalaya, a City of Santri. Second, the City of Tasikmalaya has quite a several complex problems from the shift in globalization. Third, the City Government of Tasikmalaya wants to minimize the problems in the community within the City of Tasikmalaya. Lastly, as a form of preaching, the ulama, together with the Tasikmalaya City Government, in Amar ma'ruf nahyil Munkar in the city of Tasikmalaya.

The implementation of the regional regulation still cannot be adequately implemented because it is still implemented explicitly for Muslims. Whereas in the beginning, there was another goal: to respect each other and respect each other between religions. The reasons that make this regional regulation still cannot be implemented optimally are as follows:

1. There are still shortcomings in its implementation because the regulation is still unable to answer the objectives of the regional regulation itself.

2. The agenda or program held and then implemented by the government related to Regional Regulation Number 7 of 2014 is a program that has become a habit or routine of the community itself. Such as the program of the dawn reciting movement, dress etiquette, the maghrib reciting movement, the enforcement of congregational prayers, strengthening the commemoration of Islamic holidays, and so on, which people are already accustomed to.

3. The implementation of programs run by the government is still discriminatory in nature and strongly emphasizes the character of Islam.

From the evaluation and observations, it can be conveyed that the presence or absence of these regional regulations will have the same impact because this regional regulation still does not protect the wishes of the entire community. However, if you look at it as an icon of the City of Tasikmalaya with regional regulations that protect the majority of the Islamic community, this is successful. In addition to this, there needs to be a way so that in its implementation, the community can participate and also grow awareness to realize community life following the values and norms of the City of Tasikmalaya by referring to Regional Regulation Number 7 of 2014 concerning Values of Religious Community Life in the City of Tasikmalaya. 
This means that the community must be involved and not be an object in the implementation and formulation of a policy. This Regional Regulation can be a proposal to maintain the norms and values of the people of Tasikmalaya City so that the cultivation of cultural values as a santri city in Tasikmalaya City is maintained.

\section{Acknowledgments}

This research is supported by the Master of Government Affairs and Administration, Universitas Muhammadiyah Yogyakarta, and Jusuf Kalla School of Government. He has given me an opportunity as a research fellow during my study in the master's program.

\section{References}

[1] Agustino, Leo. 2020. “Analisis Kebijakan Penanganan Wabah Covid-19: Pengalaman Indonesia Analysis Of Covid-19 Outbreak Handling Policy: The Experience Of Indonesia." Junal Borneo Administrator 16(2):253-70.

[2] AL-BARBASY, MA'MUN MUROD. 2016. "Islam Dan Negara: Perdebatan Dalam Pembuatan Perda Syariat Di Kota Tasikmalaya." Afkaruna: Indonesian Interdisciplinary Journal of Islamic Studies 12(2). doi: 10.18196/aiijis.2016.0063.223252.

[3] Al-Hamdi, Ridho. 2013. Partai Politik Islam: Teori Dan Praktik Di Indonesia. Graha Ilmu.

[4] Arfiansyah, Arfiansyah. 2015. "Implikasi Pemberlakuan Perda Syari'At Terhadap Ideologi Negara Indonesia.” Jurnal Ilmiah Islam Futura 15(1):20. doi: 10.22373/jiif.v15i1.555.

[5] Azra, Azyumardi. 2016. Transformasi Politik Islam: Radikalisme, Khilafatisme, Dan Demokrasi. Kencana.

[6] Dachi, Rahmat Alyakin. 2017. Proses Dan Analisis Kebijakan Kesehatan (Suatu Pendekatan Konseptual). Deepublish.

[7] Mahendra, Yusril Ihza. 2007. "Hukum Islam Dan Pengaruhnya Terhadap Hukum Nasional Indonesia." Makalah Disampaikan Dalam Seninar Nasional Di UIN Syarif Hidayatullah Jakarta, Tanggal 5.

[8] Nugroho, Riant. 2008. "Kebijakan Publik (Public Policy)."

[9] William N. Dunn. 2003a. "Pengantar Analisis Kebijakan Publik." 710.

[10] William N. Dunn. 2003b. "William-N.-Dunn-Pengantar-Analisis-Kebijakan-PulblikGadjah-Mada-University-Press-2003_compressed-1.Pdf." 710.

[11] Winarno, Budi. 2008. "Kebijakan Publik: Teori Dan Proses, PT.” Buku Kita, Jakarta.

[12] Winarno, Budi. 2013. "Ilmu Sosial Dan Ilmu Politik: Filsafat, Teori Dan Metodologi." Jurnal Upnyk 17(1):1-20. 